\title{
IT Governance and IT Management: Is There a Difference That Makes a Difference?
}

\author{
John Beachboard \& Kregg Aytes \\ Idaho State University, \\ Pocatello, ID, USA
}

\author{
Jack Probst \\ Pink Elephant, Inc., \\ Powell, OH, USA
}

\section{beach@isu.edu; aytekreg@isu.edu}

\begin{abstract}
This essay argues that when the distinction between IT governance and IT management becomes too ambiguous, enterprise executives may conflate the two terms, deeming their participation in IT governance activities unnecessary. This essay posits a core set of executive-level IT governance activities in which business executives should participate. These core activities include: establishment of the enterprise IT management structure, creation of the strategic IT vision and development and execution of the enterprise's IT investment priorities. The enterprise IT vision becomes the primary means for documenting high-level IT governance decisions required to facilitate the creation of an IT strategy that is truly aligned with the enterprise strategy. The guidance contained in the strategic IT vision establishes the parameters for formulating the far more detailed policies, standards that in turn inform the development of IT initiatives and the ongoing delivery of existing IT services. IT investment priorities and resulting investment decisions serve as the primary control mechanism to ensure that IT initiatives are consistent with the enterprise's strategic IT principles. This essay conceptualizes IT governance as an emergent and ongoing process requiring the cycling back and forth between IT governance activities.
\end{abstract}

Keywords: IT governance, IT management, COBIT, IT management frameworks

\section{Introduction}

One seldom hears or reads about IT management anymore; the IT trade and academic literature now abound with references to IT governance. The term "governance" is drawn from the concept of corporate governance and refers to oversight maintained by a governing board of directors over executives responsible for organizational management. Regardless of their specific title, the primary function of these corporate governing bodies is to address potential problems of "agency." We are most familiar with this concept in the context of publicly held companies where professional business executives manage firms to serve the interests of the firm's owners, the shareholders. That is, governing boards are intended to ensure that corporate executives maximize

Material published as part of this publication, either on-line or in print, is copyrighted by the Informing Science Institute. Permission to make digital or paper copy of part or all of these works for personal or classroom use is granted without fee provided that the copies are not made or distributed for profit or commercial advantage AND that copies 1) bear this notice in full and 2) give the full citation on the first page. It is permissible to abstract these works so long as credit is given. To copy in all other cases or to republish or to post on a server or to redistribute to lists requires specific permission and payment of a fee. Contact 0HPublisher@InformingScience.org to request redistribution permission. shareholder value rather than the executive's personal interests (IT Governance Institute, 2003; Kim \& Nofsinger, 2007; Peterson, 2004; Rozman, 2000; Van Grembergen, De Haes, \& Guldentops, 2004). However, the term "IT governance" is currently used to include a number of activities commonly associated with "IT management." 
In this paper, we argue that when the distinction between IT governance and IT management becomes too ambiguous, enterprise executives may conflate the two terms, deeming their participation in IT governance activities unnecessary. This essay posits, then briefly describes, a core set of IT governance activities in which business executives should participate.

The heightened interest in IT governance is largely driven by the recognition that enterprises have become increasingly dependent upon information technology. In many cases enterprises cannot function or survive without information technology. Information technology is inextricably tied into the business model, and changes in information technology can substantively influence the enterprise's overall value equation (Economist Intelligence Unit, 2008). Consequently, logic dictates that governing bodies need to oversee the setting and execution of IT strategy and the evaluation of corresponding IT risks just as they endorse and monitor organizational strategy, financial practices and executive compensation.

Probably the most cited definition of IT governance is provided by the IT Governance Institute (ITGI), a research arm of the Information System Audit and Control Association (ISACA). The ITGI defines IT governance (IT Governance Institute, 2003, p. 10):

$\ldots$ as the responsibility of the board of directors and executive management. It is an integral part of enterprise governance and consists of the leadership and organizational structures and processes that ensure that the organization's IT sustains and extends the organization's strategies and objectives.

This definition incorporates three fundamental principles common to most definitions of IT governance:

1. It assumes, if not requires, the participation of executive-level enterprise management.

2. It seeks to ensure alignment of IT strategy with enterprise strategy, goals and objectives.

3. It assesses and seeks to ensure practices are in place to minimize risks associated with the adopted IT strategy to include compliance with relevant laws, regulations and contractual obligations. (This third point is implied rather than explicitly stated in the ITGI definition. However, when ITGI documentation is reviewed in its totality, the risk management and control concerns dominate.)

Much of the ambiguity with respect to distinguishing between IT management and IT governance results from the third idea, the increasing regulatory and contractual necessity of maintaining adequate controls over an enterprise's information technology. IT failures are likely to have material impacts on enterprise performance and may have legal consequences as well. Mastercard attempted to impose a fine of $\$ 6$ million on Heartland Payment Systems as a result of the breach of Heartland's credit card payment-processing system (Vijayan, 2009) and Choicepoint has paid over \$15 million in civil penalties, customer redress and fines (Krebs, 2009). However, IT governance is not only concerned with the effective implementation of IT controls. It also includes high-level management participation in defining policies related to the implementation and use of IT in the organization.

We believe that current use of the term "IT governance" includes activities that do not necessitate business executive level involvement. We are concerned that lumping IT management and IT governance together obfuscates the importance of those IT governance activities that demand executive-level participation. Given the general acceptance and usage of the term "IT governance" to refer to a range of activities relating to IT strategy development, IT-related risk management and management oversight or control of selected IT management processes, we wish to finesse the definitional issues by confining our discussion of IT governance to executive/board level activities. We advocate a conceptualization of executive-level IT governance that remains closely, 
albeit imperfectly, aligned with traditional conceptualizations of corporate governance. This conceptualization emphasizes establishment of high-level IT-related policies and parameters to guide development and execution of an enterprise's IT strategy. For the purposes of this essay, we find it useful to describe four management groups:

- Governing boards. ${ }^{1}$ Corporate boards, boards of directors, executive and legislative oversight committees, citizen oversight committees.

- Executive-level management. Typically top-level executives with policy and strategy responsibilities who may be expected to interact directly with enterprise governing boards, sometimes referred to as $\mathrm{C}$-level executives.

- Business management. Multiple layers of non-IT management in the various functional or operational areas (e.g., accounting, HR, logistics, production, marketing).

- IT management. Those managers working within the IT activity including the CIO, recognizing that the CIO may be an active member of executive management as well.

Simply stated, executive-level IT of governance consists of those IT management-related activities (described below) that require the active engagement of board members or executive-level managers.

What do you mean when you say engagement? One possible difficulty with our criterion is establishing a clear understanding of what we mean by the term engagement. Corporate boards and executive-level management often rely on staff to produce much if not all of the documentation that the executives approve (strategies, policies, even contracts). In a sense, primary responsibility for performance of such activities may reside with the executives, but it is possible that much of the real thought that goes into producing this documentation is performed by staff or subordinate managers. It is not always clear whether the board or executives have truly taken ownership of the documentation thus created. We are not really concerned with who performed the research and staff work that went into preparing the documentation relating to IT governance that we describe below. We are concerned that the board and executives should be active participants in the development and review of the documentation and take intellectual ownership of the effort. That is what is meant by engagement with respect to our criterion.

By focusing on the responsibilities of senior enterprise executives, we avoid arguing whether the tasks of mid-level and IT managers, such as change control, or project management are IT governance or IT management. While these are important tasks, we are concentrating here on executive-level IT governance responsibilities.

Accordingly, the conceptualization of IT governance outlined in the following section is much narrower than that envisioned by ITGI and reflected in the COBIT framework. Henceforth in this essay, the term IT governance will refer to executive-level IT governance. ${ }^{2}$

\section{Executive-level IT Governance Conceptualized}

We draw upon a variety of trade and academic literature to conceptualize IT governance. Weill and Ross (2004, p. 8) describe the practice of IT governance as: "Specifying the decision rights and accountability frameworks to encourage desirable behavior in the use of IT". Perhaps ironi-

\footnotetext{
${ }^{1}$ In many corporations corporate executives are members of corporate boards and the corporate management team.

${ }^{2}$ We do not claim original authorship for emphasizing an executive perspective. We credit Peter Weill and Jeanne Ross (2004) with introducing us to the executive-level formulation of IT governance on which our conceptualization relies heavily.
} 
cally, this essay draws heavily upon their IT governance framework without fully adopting their definition of IT governance, a discrepancy that merits some explanation. Weill and Ross argue that IT governance establishes structure and responsibilities for making a selected set of ITrelated decisions. Interestingly, they found that it more important for an organization's members to understand how IT governance decisions are made than to prescribe who should be making those decisions. Weil and Ross's book is organized around the presentation of six decisionmaking archetypes: business monarchy, IT monarchy, feudal, federal, IT duopoly and anarchy (Weill, 2004; Weill\& Ross, 2004), each of which can be employed in specific IT governance decision areas. These archetypes describe different configurations or allocations of IT related decision-making authority among various groups of business and IT managers. Weill and Ross identify five interrelated decision areas as falling within the domain of IT governance (2004, p. 10):

- Establishment of IT principles - Clarifying the business role of IT

- Development of an enterprise IT architecture - Defining integration and standardization requirements

- Development of an IT infrastructure - Determining shared and enabling services

- Identification of business application needs - Specifying the business need for purchased or internally developed IT applications

- Prioritization of IT investments - Choosing which initiatives to fund and how much to spend

Under Weil and Ross's formulation then, IT governance can be conceptualized as a matrix mapping the decision archetypes employed for each of the five decision domains as depicted in Table 1. A decision archetype can then be specified for each decision area.

Table 1. IT Governance Matrix (at UPS)*

\begin{tabular}{|c|c|c|c|c|c|c|c|c|c|c|}
\cline { 2 - 10 } \multicolumn{1}{c|}{} & \multicolumn{2}{c|}{$\begin{array}{c}\text { IT Princi- } \\
\text { ples }\end{array}$} & \multicolumn{2}{c|}{$\begin{array}{c}\text { IT Archi- } \\
\text { tecture }\end{array}$} & \multicolumn{2}{c|}{$\begin{array}{c}\text { IT Infra- } \\
\text { structure }\end{array}$} & \multicolumn{2}{c|}{$\begin{array}{c}\text { Business } \\
\text { Application } \\
\text { Needs }\end{array}$} & \multicolumn{2}{c|}{$\begin{array}{c}\text { IT Invest- } \\
\text { ments }\end{array}$} \\
\cline { 2 - 10 } & $\begin{array}{c}\text { In- } \\
\text { put }\end{array}$ & $\begin{array}{c}\text { Deci- } \\
\text { sion }\end{array}$ & $\begin{array}{c}\text { In- } \\
\text { put }\end{array}$ & $\begin{array}{c}\text { Deci- } \\
\text { sion }\end{array}$ & $\begin{array}{c}\text { In- } \\
\text { put }\end{array}$ & $\begin{array}{c}\text { Deci- } \\
\text { sion }\end{array}$ & $\begin{array}{c}\text { In- } \\
\text { put }\end{array}$ & $\begin{array}{c}\text { Deci- } \\
\text { sion }\end{array}$ & $\begin{array}{c}\text { In- } \\
\text { put }\end{array}$ & $\begin{array}{c}\text { Deci- } \\
\text { sion }\end{array}$ \\
\hline $\begin{array}{c}\text { Business } \\
\text { Monarchy }\end{array}$ & & $\mathrm{X}$ & & & & & & & & $\mathrm{X}$ \\
\hline $\begin{array}{c}\text { IT Monar- } \\
\text { chy }\end{array}$ & & & & $\mathrm{X}$ & & $\mathrm{X}$ & & & & \\
\hline Feudal & & & & & & & & & & \\
\hline Federal & & & & & & & & $\mathrm{X}$ & $\mathrm{X}$ & \\
\hline Duopoly & $\mathrm{X}$ & & $\mathrm{X}$ & & $\mathrm{X}$ & & $\mathrm{X}$ & & & \\
\hline
\end{tabular}

* Adapted from Figure 1-4 (Weill \& Ross, 2004, p. 21).

In the business monarchy archetype, senior business management is primarily responsible for making the decisions within the relevant domain. In IT monarchies, the IT professionals are largely responsible for making the relevant decisions. Under a feudal archetype, decision rights are delegated to the management of the strategic business units. The federal archetype partitions decision-making authority between corporate-level and strategic business unit level management. 
The IT duopoly archetype represents a range of options for sharing decision rights between IT and non-IT managers at either the corporate or strategic business unit levels. ${ }^{3}$ Unsurprisingly, in anarchies, individual managers are given wide latitude with respect to making decisions regarding how IT will be used in their respective areas.

Our conceptualization of IT governance focuses not just on the allocation of decision rights within each of the IT-related decision-making domains, but rather attempts to more explicitly describe executive-level decision-making efforts within each of the domains (albeit slightly reconceptualized). Our fundamental concern with Weill and Ross's matrix formulation is that its definitions of decision areas do not provide sufficient granularity to inform the selection of appropriate decision archetypes. That is, a careful examination of the selection of appropriate enterprise (IT) architecture reveals that the process includes some decisions that should legitimately reside at the executive level and multiple other decisions that should be left to IT management.

To reflect this concern and more accurately represent Ross, Weill and Robertson's (2006) later work in the area of enterprise architecture, we reformulate the decision areas (as depicted in Figure 1) and operationalize the practice of IT governance by suggesting that there is a subset of activities within each domain which requires executive level engagement and should not be delegated. Concomitantly, balance of IT management (or governance) processes can be delegated to lower levels within the organization. We do not mean to imply, however, that executives should be precluded from directly participating in other IT management/IT governance activities. We encourage executives to directly involved themselves in developing IT strategies and actively monitor and evaluate IT management performance with respect to achieving enterprise goals and objectives. However, a discussion of these additional activities is beyond the scope of this essay.

Thus, we see IT governance as consisting of three primary activities: specification of the enterprise's IT management structure, development of a strategic IT vision ${ }^{4}$ (to guide development of an enterprise information architecture), and the determination of IT investment levels and priorities (see Figure 1). Note that Ross and Weill's IT architecture decision is renamed to strategic IT vision. This change aligns our conceptualization of IT governance with Ross, Weill and Robertson's (2006) subsequent call for executive-level participation in developing enterprise-level IT architectures.

The enterprise IT vision conceptualized above explicitly includes the IT principles that will govern development of the enterprise's IT strategy. The IT principles should guide the development of the high-level IT Service, Architecture, Polices and Standards, Infrastructure Policies and Standards, and high-level Security and Regulatory Compliance Policies. We adopt the term IT services architecture, policies and standards rather than application needs (as do Ross, Weill and Robertson) to be consistent with the growing influence of IT services management (ITSM) concepts on industry practice. We also modify the IT infrastructure decision area to more clearly reflect executive-level concern with formulating policies concerning IT infrastructure standardization. Finally, we recommend that high-level IT security and regularity compliance policies be included in the enterprise architecture. Note our use of the term "high-level" with respect to these three policy domains.

\footnotetext{
${ }^{3}$ This represents the briefest possible description of these archetypes and their use. The interested reader is encouraged to consult the original source material (Weill \& Ross, 2004; Weill, 2004).

${ }^{4}$ The term vision can be considered problematic as the term is subject to various usages. In this context we use the term only to refer to executive-level management decisions and directives that inform the explicit development of the enterprise IT management structure, practices and IT service strategy.
} 


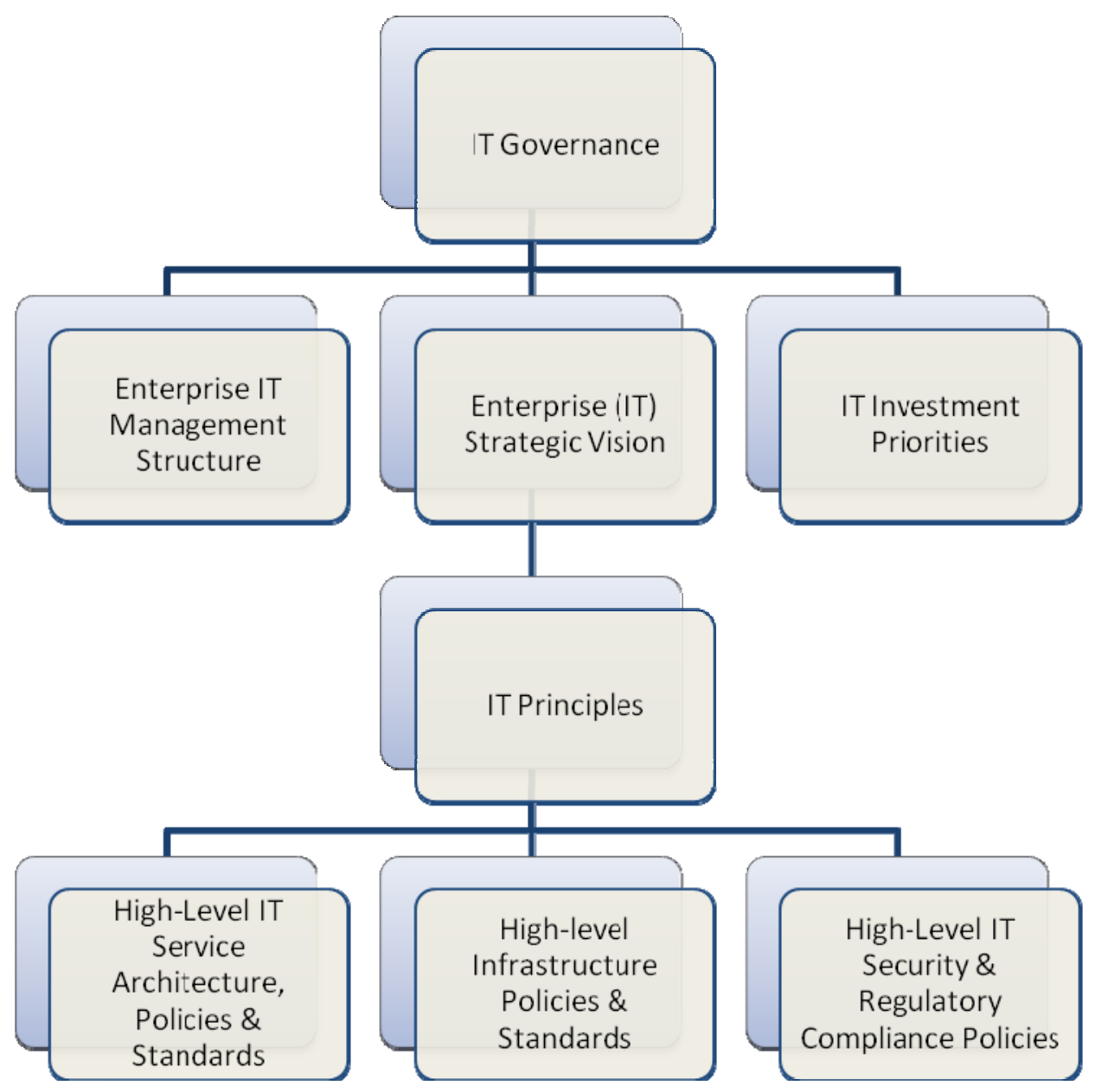

Figure 1. IT Governance Reformulated

Under our conceptualization, the enterprise IT vision becomes the primary means for documenting high-level IT governance decisions required to facilitate the creation of an IT strategy that is truly aligned with the enterprise strategy. The guidance contained in the strategic IT vision establishes the parameters for formulating the far more detailed policies, standards that in turn inform the development of IT initiatives and the ongoing delivery of existing IT services. IT investment priorities and resulting investment decisions serve as the primary control mechanism to ensure that IT initiatives are consistent with the enterprise's strategic IT principles.

The conceptualization of executive-level IT governance depicted at Figure 1 should be interpreted in terms of a work breakdown structure, a convenient means of organizing deliverables commonly employed by project managers, rather than a process diagram. Ironically, we would have preferred to create a process diagram but found the creation of such a complex diagram to be beyond our artistic capabilities. Explaining the rationale used in reaching this conclusion provides an opportunity to emphasize what we believe to be an important consideration relevant to establishing enterprise IT governance.

A process typically implies an ordered or structured set of activities. While we find it useful to conceive of IT governance as consisting of the activities associated with the production of the three major deliverables identified. However, we do not believe it possible to unambiguously suggest an order in which these activities should be performed. Executive level IT governance 
represents a gestalt process: the activities involved in the creation of deliverables are mutually informing and must be conducted in concert with one another. So while one might argue it reasonable to first establish the IT management structure, then develop the IT vision and establish investment priorities on the basis of that vision, existing financial priorities might well drive the selection of IT principles (e.g., relating to the degree of IT service standardization and integration the enterprise seeks to attain) informing the development of the IT management structure. In short, we see IT governance as an emergent and ongoing process requiring the cycling back and forth between IT governance activities. Furthermore, the IT governance process is not selfcontained. At a minimum, executives should actively seek the input from the enterprise staff if not engage in an ongoing dialogue where concepts and proposals are shared and discussed throughout the organizational chain.

Consistent with the view that IT governance is a continuing requirement, we envision numerous iterations in the thinking and decision-making activities outlined above. Achieving IT governance success will largely depend upon executive management's ability to fluidly move among the three domains appreciating their nuances and interdependencies.

\section{Conclusion}

The primary purposes of this essay were to:

1. Argue that there is a difference between IT management and IT governance that makes a difference, particularly when one considers IT governance from an executive-level perspective.

2. Briefly outline how executive-level IT governance might be conceptualized.

The topics of IT management and IT governance are complex. There are many processes associated with the overall management of IT. Sorting those processes into governance and management categories is difficult.

We have defined executive-level IT governance as consisting of those high-level IT management activities which merit direct executive-level engagement and provide the foundation upon which the enterprise IT strategy is built. Drawing heavily upon the research of several thought leaders in the IT discipline, we have identified a subset of processes or activities we believe merit executive-level engagement. Critical IT decisions are made even with indecision; critical IT principles evolve in organizations even without direct executive-level participation. Perhaps the results of an anarchic decision-making process may prove adequate, even successful. However, our view is: executives abrogate their responsibilities when they let critical IT decisions and principles evolve within the enterprise without their direct participation and guidance. Executives, at a minimum, should be prepared to:

- Define IT management roles and responsibilities at the enterprise level.

- Articulate the IT principles that establish general parameters governing how information technology is to be employed in the enterprise.

- Prioritize and establish sufficient controls to ensure that IT investments are consistent with established IT principles.

In making this argument we do not wish to imply that strategic initiatives necessarily originate at the executive level. In a healthy enterprise the strategic initiatives might emerge from any organizational level. However, the responsibility for evaluating whether those initiatives should be pursued resides at the executive level. 
Furthermore, IT governance should not be seen as stifling innovation. If the enterprise architecture and the associated IT standards, risk policies and investment strategy impede the development of creative solutions to business problems or limit the pursuit of technology-enabled opportunities, that is a sure sign that the enterprise's strategic IT vision needs to be reviewed. Thus, even within the context of what may appear to be a top-down model of IT governance and management, the need for change may be driven from below.

Consistent with the perspectives of the ITGI and others, we believe that IT governance requires explicit consideration of IT-related risk and requires the establishment of internal structures required to monitor and control execution of the enterprise IT strategy. But in drawing on the literature of corporate governance, we want to ensure that we not confuse the need for executivelevel governance oversight with direct supervision of various IT management controls.

From the foregoing discussion, one might conclude the topic of IT governance is germane only to large commercial or public enterprises and of little interest to small businesses and not-for-profit organizations. We do not agree with this view. Small businesses and organizations often rely extensively on information technology. In conceptualizing executive level IT governance, we have described minimal processes required to obtain only that information that should legitimately come from those responsible for developing the enterprise direction and strategy.

Such information does not require the creation of lengthy or elaborate documentation commonly associated with IT strategic plans and enterprise architectures. It can be presented concisely, perhaps even orally. The most important element of the entire IT governance effort is to ensure that organizational leadership takes the time to think about the issues identified and to clearly communicate the results of its deliberations. As smaller organizations are typically more tightly constrained in discretionary resources, the establishment and execution of an appropriate IT governance framework may well be of greater importance to small- and medium-sized enterprises (SMEs) than to corporate giants and massive government agencies.

Some executives will likely remain reluctant to participate in the activities outlined above. They may be concerned about the time commitment or they may have concerns as to whether they have the technical knowledge required to make these important decisions. While a broad understanding of information technology and its application with the particular enterprise domain would certainly be beneficial, we encourage reluctant participants to carefully review our proposals. The activities and decisions outlined constitute business rather technical decisions. We are not asking executives to develop the enterprise strategy (although we certainly do not mean to preclude executive level participation in IT strategy development). We are asking executives to effectively articulate their philosophy and attitudes regarding how they expect information technology to contribute to executing the enterprise strategy and establish an IT management structure capable of ensuring that IT practices and initiatives are aligned with the their overarching IT vision.

\section{References}

The Economist Intelligence Unit. (2008). Closing the IT business gap. Retrieved 10 November 2009, from The Economist: http://viewswire.eiu.com/report dl.asp?mode=fi\&fi=1623298147.PDF\&rf $=0$

IT Governance Institute. (2003). Board briefing on IT governance (2nd Edition). Retrieved 11 November 2008, from IT Governance Institute: http://www.isaca.org/ContentManagement/ContentDisplay.cfm?ContentID=39649

Kim, K. A., \& Nofsinger, J. R. (2007). Corporate governance. Upper Saddle River, NJ: Pearson Prentice Hall. 
Krebs, B. (2009, October). ChoicePoint breach exposed 13,750 consumer records. The Washington Post. (Blog). Retrieved 10 November 10, 2009, from http://voices.washingtonpost.com/securityfix/2009/10/choicepoint breach_exposed 137.htm

Peterson, R. R. (2004). Integration strategies and tactics for information technology governance. In W. Van Grembergen (Ed.), Strategies for information technology governance (pp. 37-80). Hershey, PA: Idea Group Publishing.

Ross, J. W., Weill, P., \& Robertson, D. C. (2006). Enterprise architecture as strategy: Creating a foundation for business execution. Boston, MA: Harvard Business School Press.

Rozman, R. (2000). The organizational function of governance: Development, problems, and possible changes. Management, 5(2), 94-110.

Van Grembergen, W., De Haes, S., \& Guldentops, E. (2004). Structures, processes and relational mechanisms for IT governance. In W. Van Grembergen (Ed.), Strategies for information technology governance (pp. 1-36). Hershey, PA: Idea Group Publishing.

Vijayan, J. (2009, 11 May). Heartland breach costs at \$12.6M - and counting. Computerworld. Retrieved 13 May 2009, from Computerworld, Inc.: http://www.computerworld.com/action/article.do?command=viewArticleBasic\&taxonomyN $\underline{\text { ame }=\text { network security\&articleId }=9132864 \& \text { taxonomyId }=142 \& \text { intsrc }=\mathrm{kc} \text { top }}$

Weill, P. (2004). Don't just lead, govern: How top-performing firms govern IT. MIS Quarterly Executive, 3(1), 1-17.

Weill, P., \& Ross, J. W. (2004). IT governance: How top performers manage IT decision rights for superior results. Boston, MA: Harvard Business School Press.

\section{Biographies}

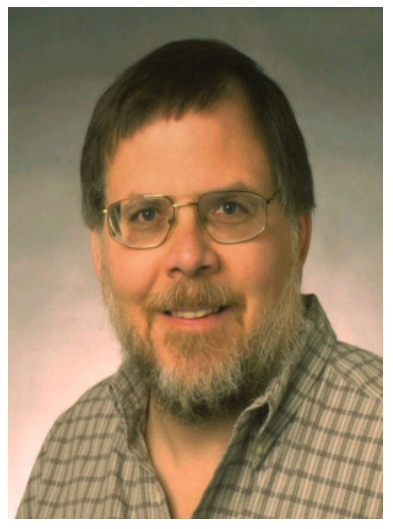

John Beachboard is professor of Computer Information Systems at Idaho State University. He has more than 25 years' experience implementing large-scale information technology and telecommunications systems and directing the Army's Data Network Control Center in Europe. In 2004, he received an AIS Award for Innovation in IS Education for his work incorporating IT service management concepts in the CIS curriculum at ISU. His teaching and research interests emphasize practical approaches for delivering and operating secure, costeffective IT services. He is a member of AIS, ACM, and itSMF. 


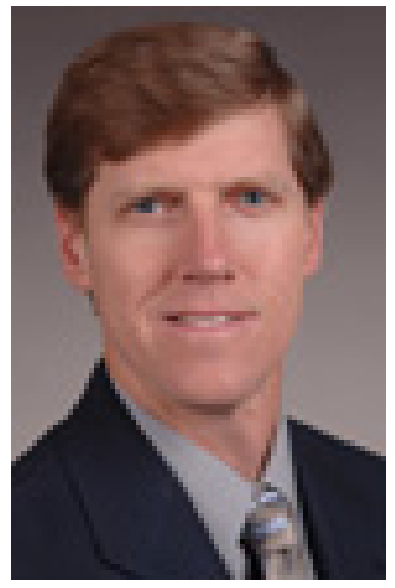

Kregg Aytes has been a member of the Computer Information Systems faculty at Idaho State University since 1993. He completed his Ph.D. at the University of Arizona in that same year. Kregg teaches graduate and undergraduate courses in CIS, served as department chair, and is now Associate Dean for the College of Business. His research interests include information security, IT service management, and collaborative technologies. He also has a strong love of teaching and is interested in the application of IS content and skills across the business school curriculum.

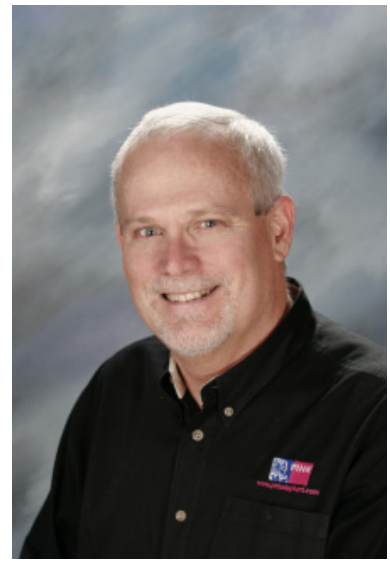

Jack Probst has a diverse management, business and technical background, and he delivers strategic process consulting and advanced ITIL $^{\circledR}$ training and education programs as a Principal Consultant for Pink Elephant. An ITIL Expert, Jack previously served as the leader of an ITIL implementation initiative at a Fortune 100 organization. He also possesses decades of experience in IT process development and implementation, IT and business strategic alignment, business operations and general management. Additionally, Jack is a seasoned speaker and graduate-level educator, and is a member of the (itSMF) Academic Subcommittee that was recognized with the 2007 Industry Knowledge Contribution Award. 